\title{
Testicular Cancer cT4 TNM Finding v8
}

National Cancer Institute

\section{Source}

National Cancer Institute. Testicular Cancer CT4 TNM Finding v8. NCI Thesaurus. Code C140197.

Testicular cancer in which the tumor invades scrotum with or without vascular/lymphatic invasion. (from AJCC 8th Ed.) 